Sains Malaysiana 49(9)(2020): 2065-2072

http://dx.doi.org/10.17576/jsm-2020-4909-04

\title{
Implementation 3D Inversion of Gravity Data to Identify Potential Hydrocarbon Reservoir Zones in West Timor Basin
}

\author{
(Implementasi Songsangan 3D pada Data Graviti untuk Mengenal Pasti Potensi Zon Reservoir Hidrokarbon di
} Lembangan Timor Barat)

\author{
MOHAMMAD SYAMSU Rosid* \& CICILIA BUdi SARASWATI
}

\begin{abstract}
A gravity survey has been carried out in the area of West Timor, East Nusa Tenggara to identify the existence of basin structures. The existence of reservoirs and trap structures are two important parameters in hydrocarbon exploration. Geologically, Timor possibly an area known to have a very complex geological structure. This complexity can be the main factor that causes the demotivation of geologists in exploring hydrocarbons. There are many indications of hydrocarbons in the form of oil and gas seeps on the surface, especially in East Timor. But most of them are not confirmed in the field, and only a few are even found in West Timor. The method used in this study is analyzing and $3 D$ inversion modeling gravity data. The analysis was carried out using spectrum analysis and the second vertical derivative of the complete Bouguer anomaly (CBA). From the gravity parameters confirmed by geological data, the results indicate that in the study area there are basin and basement structures thought to be formed from unconformably of andesite igneous rock and tight send sediment with a density value of about $2.5 \mathrm{gr} / \mathrm{cm}^{3}$. The average basement depth is about $5.5 \mathrm{~km}$ with its forming structure is the reverse/thrust fault with Northeast to Southwest its strike orientation. While in the southern part, especially in the central basin area, there is indicated a layer of sand sediment that is quite thick with a density value of about $2.2 \mathrm{gr} / \mathrm{cm}^{3}$ and has the potential to become a hydrocarbon reservoir.
\end{abstract}

Keywords: East Nusa Tenggara; gravity method; hydrocarbon exploration; Timor basin

\section{ABSTRAK}

Suatu survei graviti telah dijalankan di daerah Timor Barat, Nusa Tenggara Timur untuk mengenal pasti keberadaan struktur lembangan di situ. Keberadaan reservoir dan struktur perangkap adalah dua parameter penting dalam eksplorasi hidrokarbon. Secara geologi, Timor mungkin merupakan satu daerah yang diketahui memiliki struktur geologi yang sangat kompleks. Kekompleksan ini menjadi faktor utama yang menyebabkan motivasi para geologis berkurang dalam melakukan eksplorasi hidrokarbon di sana. Banyak ditemukan petunjuk hidrokarbon dalam bentuk rembesan minyak dan gas di permukaan terutama di daerah Timor Timur. Tetapi kebanyakan daripada mereka tidak dapat dipastikan di lapangan dan hanya beberapa bahkan ditemukan di wilayah Timor Barat. Kaedah yang digunakan dalam kajian ini adalah melakukan analisis data graviti dan pemodelan songsangan $3 D$. Analisis dilakukan dengan menggunakan analisis spektrum dan turunan menegak kedua daripada anomali Bouger lengkap (CBA) data graviti. Daripada parameter graviti yang dipastikan oleh data geologi, hasilnya menunjukkan bahawa di kawasan kajian terdapat struktur lembangan dan dasar yang diduga terbentuk daripada batuan beku andesit yang tidak selaras dengan endapan pasir keras dengan ketumpatan sekitar $2.5 \mathrm{~g} / \mathrm{cm}^{3}$. Purata kedalaman dasar ini ialah $5.5 \mathrm{~km}$ dan membentuk struktur sesar tujah dengan arah jurusnya Timur laut ke Barat daya. Sementara di bahagian Selatan, terutama di pusat lembangan, menunjukkan adanya lapisan endapan pasir yang cukup tebal dengan ketumpatan $2.2 \mathrm{~g} /$ $\mathrm{cm}^{3}$ dan berpotensi untuk menjadi reservoir hidrokarbon.

Kata kunci: Eksplorasi hidrokarbon; kaedah graviti; lembangan Timor; Nusa Tenggara Timur

\section{INTRODUCTION}

Indonesia is currently experiencing a deficit of fossil fuels and is therefore one of the oil-importing countries. Indonesia's oil demand continues to increase, while its production continues to decline. Various efforts have been made by the government, ranging from optimizing production to maximizing exploration. In the eastern region of Indonesia in Timor Island, a study has been conducted in a sedimentary basin suspected of having hydrocarbon potential. Timor Island is politically divided 
into two main parts: East Timor as Timor Leste country and West Timor as part of the province of Nusa Tenggara Timur (NTT), Indonesia. Timor has many folds and faults as a result of collisions between the Australian plate in the South and the Banda Arc in the North. There are also a lot of gas and oil seeps are found in Timor Island (Figure 1) (Harsolumakso et al. 2019). Therefore, hydrocarbon exploration in Timor has been begun for more than 60 years. However, most of the manifestation in East Timor was not confirmed, and only a few of them are proven in West Timor (Harsolumakso et al. 2019). West Timor, palaeogeographically, was a predominantly basinal area lying at the northern end of the Palaeozoic Bonaparte Graben aulacogen (Bird \& Cook 1991), and it may also form part of a predominantly gas province along this old graben trend.

In geological approach, thin-skinned models for fold and thrust belts have been popular over the last $2-3$ decades, and still offers a good explanation for the style of deformation in the basinal successions of central West Timor (the Kolbano-Kekneno areas) (Sani et al. 1995). However, geological structures in Timor is very complex. The complexity of structure is a major cause to discourage hydrocarbon exploration. Charlton (2002) said that this complexity is largely restricted to shallow structural levels only and below this large and relatively simple inversion structures are to be found, with the potential to host giant hydrocarbon accumulations. Therefore, the basement-involved structures approach is a recently recognized play role in many fold belts. The basement probably plays an important role in Timor tectonics, particularly in the palaeogeographical higher-standing areas of eastern Timor (Chamalaun \& Grady 1978). Since geological data more sensitive to the shallow layer only, the huge and relatively deep and regional basement is more precisely, easier, and better to map by using a geophysical approach. The study aims to identify the basement structure in the West Timor area through gravity data. The gravity method is one of the geophysical methods based on the measurement of gravitational field variations. This variation of the earth's gravitational field is caused by the difference in mass density between rocks. The gravity data is more sensitive to the lateral variation of rocks. A good and correct gravity data analysis can produce qualitative and quantitative interpretation. Modeling can also be done as a quantitative interpretation of gravity data. 3D inversion modeling of gravity data can provide a detailed description of the subsurface structure. Besides, this modeling can provide more convincing information in determining both the location of the fault and the location of the reservoir in the study area.



FIGURE 1. There are lots of manifestations of oil and gas seeps in Timor Island

(Charlton 2001) 


\section{MATERIALS AND METHODS}

\section{REGIONAL GEOLOGY}

Regionally, the geological structures in Timor Island are very complex. The main structures found include folds, reverse/thrust faults, and shear faults. The growing geological structure is generally shaped by the NorthwestSoutheast (NW-SE) mainline collisions. The complex geology of Timor is the result of the collision of the Northwest Australian Plate with the Banda Arc so that the Australian Continent crust dips under the arc of the archipelago in the direction of the inclination to the North. The event of the collision is expected to occur at the end of the Miocene. The collision initially taken place in the central part of Timor and then moved to the Southwest at a speed of about $110 \mathrm{~km} / \mathrm{Ma}$ (Harris 1991).

The area of West Timor can be divided into three physiographic zones, namely the Northern Range where there are rows of harsh topographically dense, rugged Central Basins with sloping slopes composed by synorogenic clastic deposits endless neither endogenous carbons and the Southern Range is characterized by a row of hills which is a series of rising sheets (Sani et al. 1995).

\section{STRATIGRAPHY AND PETROLEUM SYSTEM}

Stratigraphy of West Timor can be divided into three sequences which are Kekneno, Kolbano, and Viqueque Sequences (Sawyer et al. 1993). Whilst East Timor is a distal part of the Australian Continent Plate consisting of sedimentary rocks with shallow-marine depositional environments. The formation began at Permian whereas the basin formed a syn-rift phase during the extensional phase. Sedimentary rocks were deposited in shallow to deep marine environments. At the end of the Jurassic, the Australia continent experienced a break-up with Gondwana which raised volcanic unconformity marked by deep ocean. At the age of Cretaceous to Early Miocene post-rift phase occurred which was characterized by the formation of passive margin sediments. At the age of Late Miocene, a collision occurred between the Banda Arc and the Australian Continent. At the end of the Pliocene, tectonic tended to be relatively quiet. The tectonic evolution of Timor influences sedimentation the Permian syn-rift basin is indicated by the appearance of lake deposits which gradually changes into shallow marine sediment in the Jurassic. On the other hand, sedimentation patterns in the post-rift phase during Cretaceous to Early Miocene are characterized by shallow marine sediments.

The petroleum system is generally consisting of 4 main parameters that are source rock, reservoir, caprock, and trap. Koesnama and Permana (2015) have identified several formations as a potential reservoir in West Timor. The reservoir as an accumulated hydrocarbon site is an important factor in identifying a potential petroleum system. The formations are Cribas Formations that have smooth to medium sandstone from the late Permian, Babulu Formations that contain medium to rough sandstone, Aitutu Formations of limestone, and Oebaat Formations that have medium to rough sandstones and contain a late Jurassic belt. A cap rock layer is also identified as shale from the Cribas Formation, shale, and claystone in Triassic rock units and shale or claystone on the Nakfunu Formation have excellent potential as cover rocks. Generally, the megascopic characteristics in the field show as an impermeable and very tight layer. The results of petrographic analysis also show that the shale from these rock units has very bad porosity which the pores are already filled by either clay or carbonate minerals. Therefore, these rock units are excellent for becoming a hydrocarbon covering rock on the Timor Basin (Koesnama \& Permana 2015).

Geological and geophysical analysis identified two possible types of hydrocarbon traps in this study area. The traps are structures trap and stratigraphic traps. The growing structural traps are the positive flower structure, sloping anticline, rising anticline, and graben. While the stratigraphic trap may be sandstone lenses and limestone layers. Seismic data in the Timor Sea also indicates anticline and monoclinic structures in the West Timor Sea that is associated with the fault section, which may serve as structural traps. While in the Timor Sea from East to the South of Timor Island is also found anticline and monocline associated with fault. This is also a potential trap in the Timor Basin (Koesnama \& Permana 2015).

\section{METHODS}

The study is done by using gravity data only that has been acquired by PT Pertamina. The complete Bouguer anomaly (CBA) of gravity data is then analyzed and modeled to figure out the subsurface structure in this study area. Spectrum analysis, first horizontal and second vertical derivative is applied through gravity data to characterize both qualitatively and quantitatively of the existence of structure. Spectrum analysis is applied here to generate both regional and residual anomaly map. It also used to estimate the depth of the relatively high-density basement. First horizontal (FHD) and second vertical derivative (SVD) methods are implemented here to estimate the location as well as the type of structures. The SVD method can identify the type of structure either as a normal or reverse fault. However, the methods could not use to map directly the dip of the structure, it only able to map the strike of the structure. Whilst the 3D inversion of gravity data is implemented to identify the model volume of basin structure. The model, of course, considers the results of previous methods. The flow of work in this study can be seen in Figure 2. 


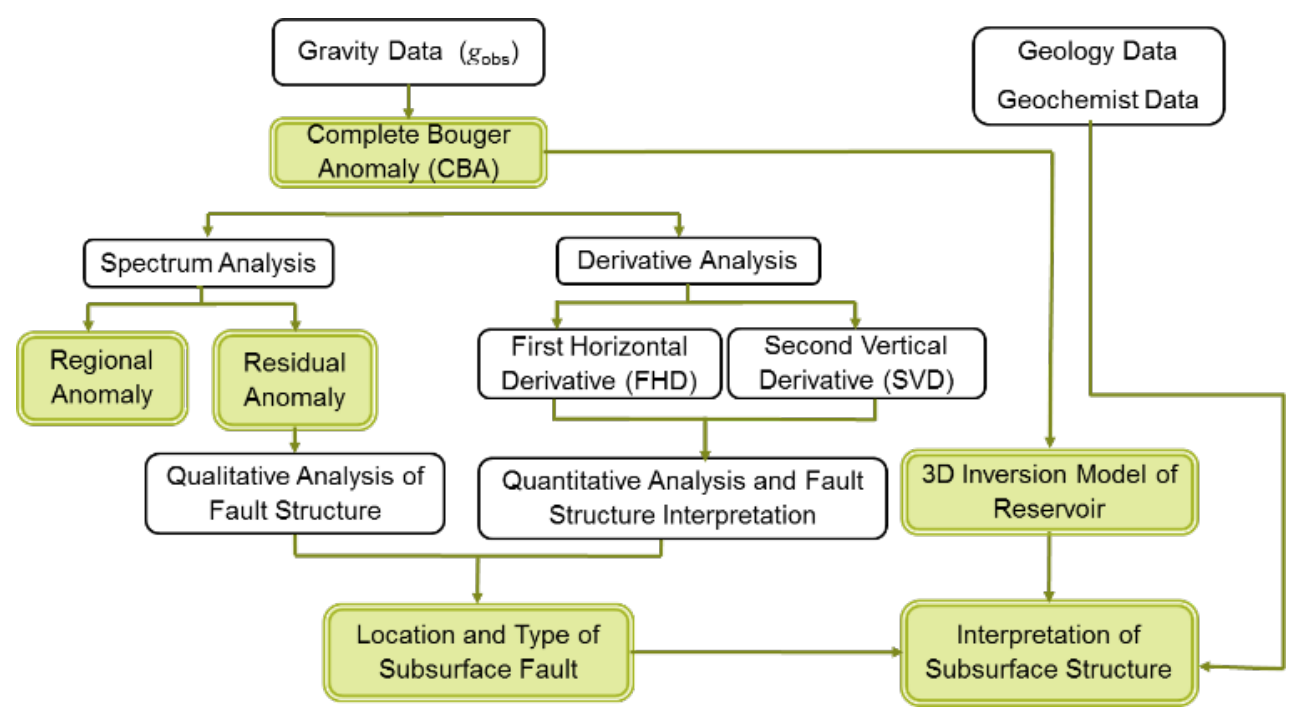

FIGURE 2. Flowchart of 3D inversion of gravity data

\section{RESULTS AND DISCUSSION}

The contour maps of regional and residual anomaly (Figure 3) are obtained after implementing spectrum analysis and moving average into the complete Bouger anomaly data. From the regional anomaly contours (Figure 3(a)), it can be said that the northern area is characterized as high gravity zone, and contrarily in the southern area is dominated by relatively very low gravity. The regional contour map of the gravitational field is associated with a deep and wide body anomalous. It can be suggested that there is a regional, big, and deep structure with Northeast-Southwest (NE-SW) orientation. The fault structure clearly separates the high and low gravity zones.
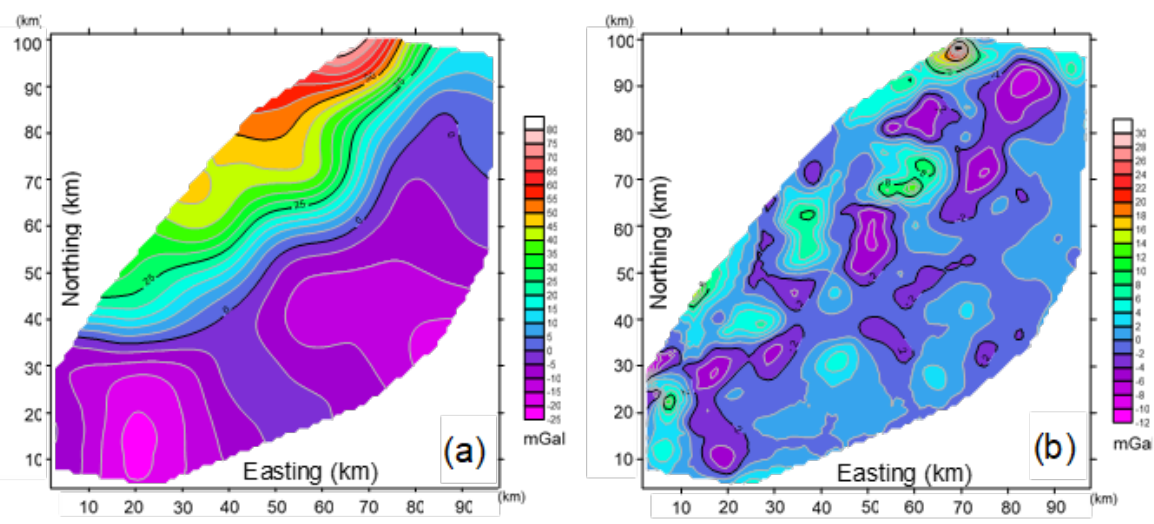

FIGURE 3. Contour map of (a) regional anomaly and (b) residual anomaly

Since the goal of the study was to determine the basement structure in this area, the data analysis is more focused on gravity regional anomaly only. The basic concept spectrum analysis method works to estimate the depth of anomaly object regionally, then the method is also used to know the shape of the structure of anomaly object according to its depth (Rosid \& Setiawan 2015). There are three paths made in this process (Figure 4), lines of AA, BB, and CC. The estimation of the basement structures in each line can be seen in Figure 4(b). 


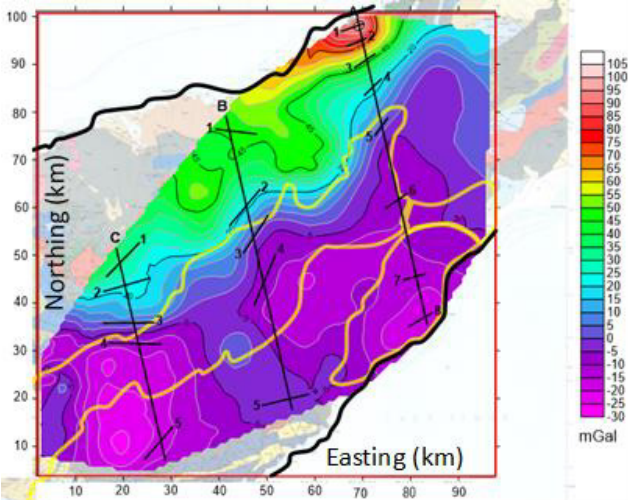

(a)

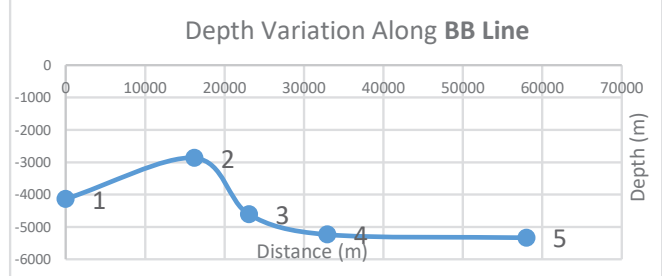

(b)

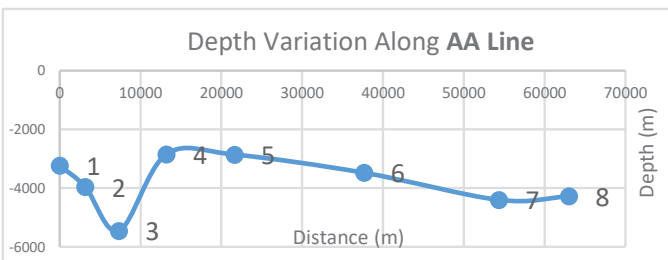

(b)

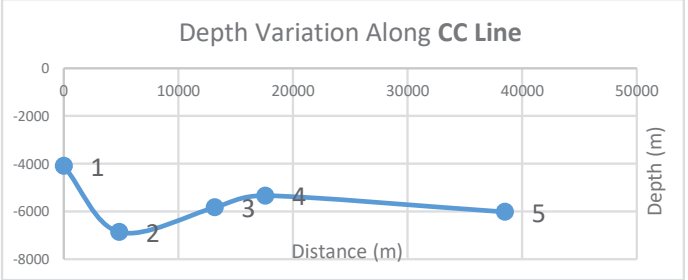

(b)

FIGURE 4. (a) Overlay of a geological map, CBA plane projection contour map, basement structure estimation path, baseline boundary line and border central basin characterized by the yellow line, and (b) Structural estimation graph for path A, path B, and path C

According to the depth value of the color based on spectrum analysis shows that the depth of estimated basement at line A for top and bottom are at $2846.6 \mathrm{~m}$ deep and $5456.8 \mathrm{~m}$ deep, respectively. Meanwhile, on path $\mathrm{B}$ and $\mathrm{C}$ the results show that the estimated depth of the basement tends to rise and getting deeper which are on line B the top $=2870.2 \mathrm{~m}$ and bottom $=5335.1 \mathrm{~m}$ deep and on path $\mathrm{C}$ the top $=4087.6 \mathrm{~m}$ and bottom $=6862.4 \mathrm{~m}$ deep. This suggests that the basement basin from track $\mathrm{C}$ to track A (from West to East) is increasing or shallower. It might be related to Charlton (2002) suggestion that a large basement-involved inversion structure underlies the Kolbano thin-skinned imbricates, and that this structure has considerable hydrocarbon potential.

\section{D INVERSION MODELING}

The Grav3D inversion results show the density contrast value. The distribution of density values of the subsurface material model in the study area ranged from 1.45 to 2.94 $\mathrm{g} / \mathrm{cc}$, which the average density is equal to $2.20 \mathrm{~g} / \mathrm{cc}$.

The first is cut off on the Grav3D model of CBA data that has been projected onto the plane (Figure 5). This is done to see the form of basement estimation that exist in the study area. The basement section is estimated to have a density of more than $2.5 \mathrm{~g} / \mathrm{cm}^{3}$ and should be cut off with a minimum value of $2.5 \mathrm{~g} / \mathrm{cm}^{3}$.

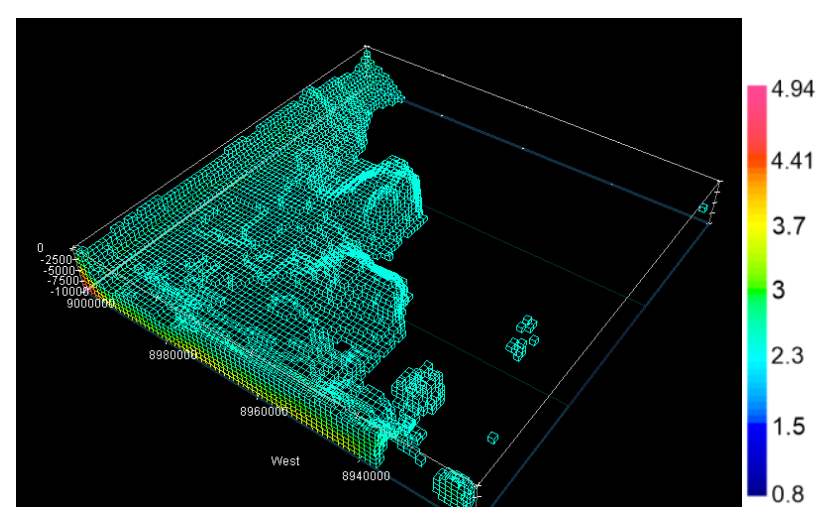

(a)

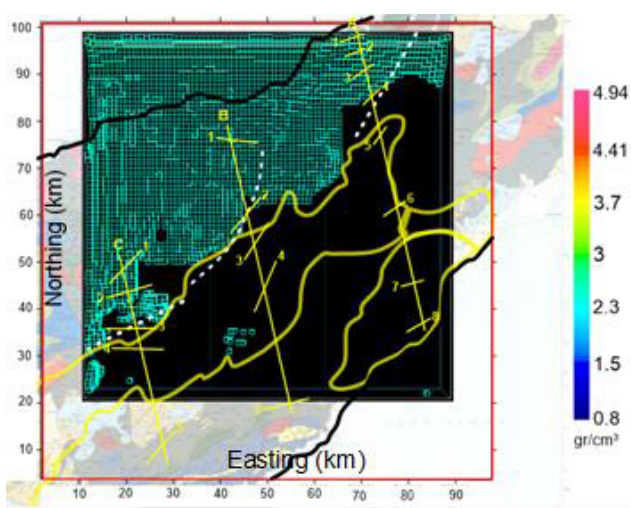

(b)

FIGURE 5. (a) The CBA inversion model is cut off for basement structure estimation, and (b) Overlay geological map, sectional spectrum analysis slicing, fault slicing, and 3D cut off inversion model at least $2.5 \mathrm{~g} / \mathrm{cm}^{3}$ 
Overlay results (Figure 5) correspond to the basement structure analysis statements made per color, that the depth of the basement from the West to the East is shallower and there is a decrease in-depth in the center when viewed from the North to the South. Meanwhile, for the southern part of the study area, there is an unclearly detectable body basement, it might be due to the area is in a low gravity anomaly and has a very low rock density value.

In Figure 6, it can also be seen more clearly that the fractures formed in the study area are a reverse fault that confines the basement region with the estimated area as a thick layer of sediment. The fault is located in the northern part of the central basin. The existence of thrust faults here is also confirmed by Charlton (2002) as well as verified by Koesnama and Permana (2015) that graben as one of the structure traps here as mention before. We believe that the $3 \mathrm{D}$ inversion model cut off at a value of at least 2.5 $\mathrm{g} / \mathrm{cm}^{3}$ is associated with the basement of the study area. Therefore, it can be expected that the basement layer of the study area looks likely combining the type of andesite igneous rock and tight sand sediment which may have a density range of about 2.4 to $2.8 \mathrm{~g} / \mathrm{cm}^{3}$. It was confirmed by Audley-Charles (2004) who stated that the basement is unconformably overlain in different places by volcanic and sedimentary rocks. Lots of manifestations of mud volcano in the northern area of West Timor as shown in Figure 1 might indicates the existence of an igneous rock basement. Weakly magnetic intensity as mentioned by Charlton (2002) and claimed of Sani et al. (1995) that the area is dense and topographically harsh area, shows that the northern area has experienced demagnetization process due to the impacts of thermal activity and compaction of sediment rocks. Thick-skinned nature of the thrust faults has brought to diminish the hydrocarbon potential in the northern West Timor. It can explain why the manifestation of oil seeps in West Timor less than in East Timor. Therefore, the unconformity of andesite rock and tight sand sediment here is believed as a basement layer. The basement rock here is believed as a part of Kekneno Formation. Based on a field study by Sawyer et al. (1993), the basement rocks in Timor are uplifted and outcropped to the surface area. The uplifted and outcropped the basement rock to the surface in the North of study area is indicated by very high gravity value. However, the affinity of basement rocks that outcrop on Timor is not well understood. The existence of the basement in Timor that was associated in the field with Kekneno Sequence is also verified by Ricardo et al. (2017).

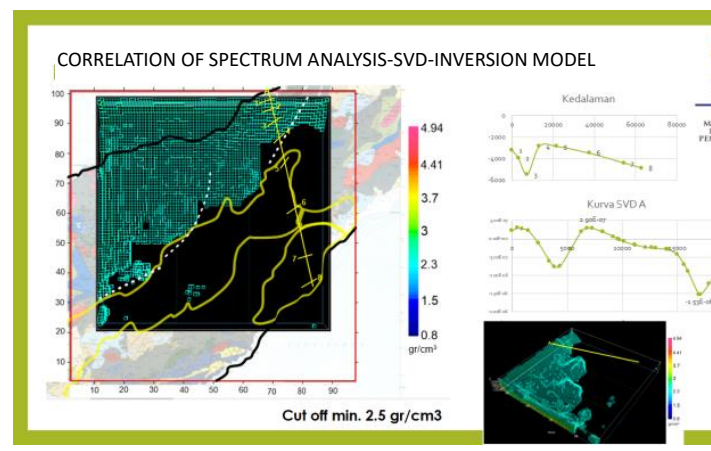

(a)

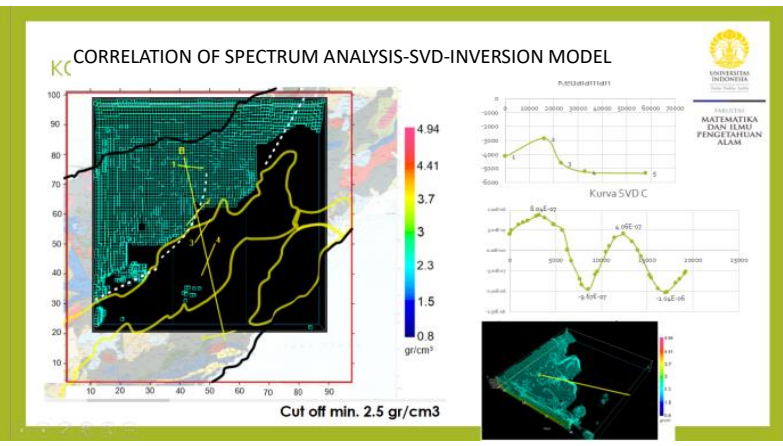

(b)

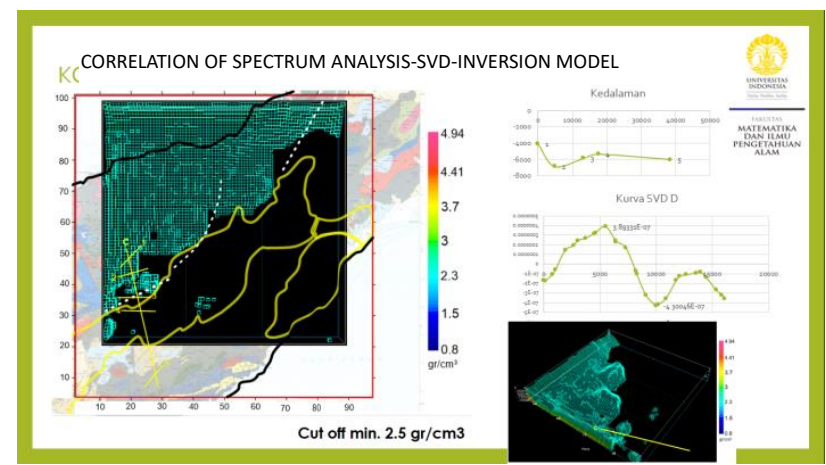

(c)

FIGURE 6. (a) Overlay of a geological map, spectrum analysis of line A, A fault slicing, and 3D cut off inversion model of at least $2.5 \mathrm{~g} / \mathrm{cm}^{3}$, (b) Overlay of a geological map, spectrum analysis of line B, C fault slicing, and 3D cut off inversion model of at least $2.5 \mathrm{~g} / \mathrm{cm}^{3}$, (c) Overlay of a geological map, spectrum analysis of line C, D fault slicing, and $3 \mathrm{D}$ cut off inversion model of at least $2.5 \mathrm{~g} / \mathrm{cm}^{3}$ 
The 3D inversion model is also cut to the maximum value of a density of $2.2 \mathrm{~g} / \mathrm{cm}^{3}$. The goal is to see if the invisible part of the cut off the basement area is a sedimentary layer whose density value is very small. In Figure 7, it can be seen that the fractures detected in the derivative analysis are indeed confined to the estimated area as the basin and the estimated area as a thick layer of sediment. The thick layers of sediment in the central basin to the South of the study area are thought to be potential reservoir zones as they are a sedimentary layer. This is verified by Koesnama and Permana (2015) which states that the structural trap type in the Kekneno block (Northern Range) is a rising anticline and the type of stratigraphic trap lenses sandstone. By following the
SVD results where fractures are detected in the area of the Kekneno block and reverse fault. Similarly, sediment layers that have a maximum density of $2.2 \mathrm{~g} / \mathrm{cm}^{3}$ in the region of the central basin to the South are a type of sand sedimentary rock (with a rock density of 1.7 to $2.3 \mathrm{~g} /$ $\mathrm{cm}^{3}$ ). This estimation matches the results of petrographic analysis which states one of the potential formations as a hydrocarbon reservoir is the Oebaat Formation in the Kolbano Block which consists of medium-coarse sandstone, round grain shape, good sorting, and the mineral composition is quartz. Also, the older rocks under the Kolbano sequence making the south and southeast region of the Timor Basin maintain the hydrocarbon potential (Harsolumakso et al. 2019).

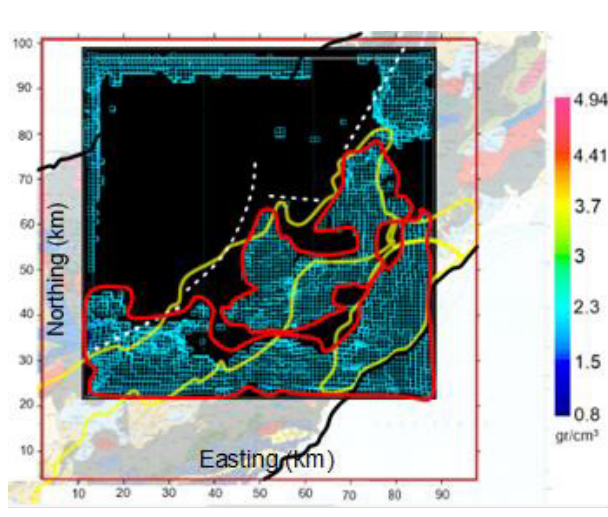

(a)

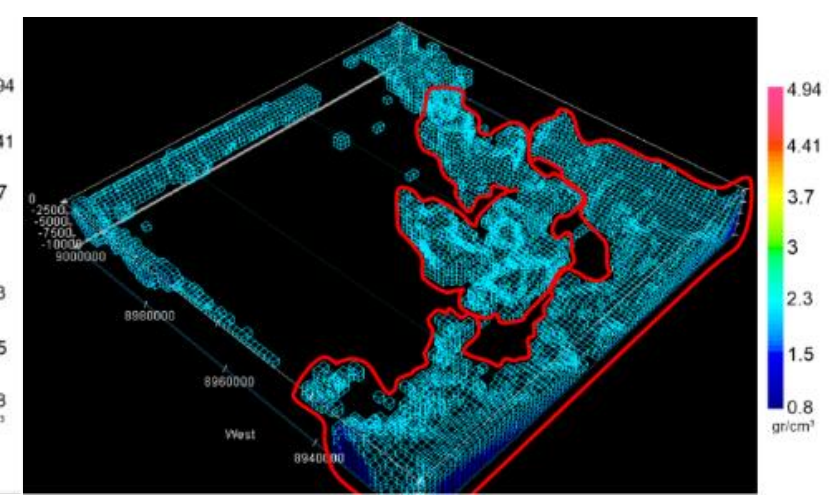

(b)

FIGURE 7. (a) Overlay geological map and target of an estimated hydrocarbon reservoir zone from the inversion model, and (b) Estimated target of hydrocarbon reservoir zone viewed in $3 \mathrm{D}$

\section{CONCLUSION}

West Timor area gravitically can be divided into two main parts: Northern high gravity and southern low gravity. Both areas are separated by thrust fault in NE-SW strike orientation as major faults orientation. The North part is believed as Kekneno basement rock which is outcropped to the surface area. The South part is believed as a basin of the Kolbano depression area. In the central part of the basin (the middle to the South of the study area) has a fairly thick layer of sediment, while in the North the basin tends to be shallower. This thick part is believed to have potential as a hydrocarbon reservoir. The potential area of hydrocarbon reservoir has a very small density of less than $2.2 \mathrm{~g} / \mathrm{cm}^{3}$ estimated to enter the sand sedimentary rock type (with a rock density range of $1.7-2.3 \mathrm{~g} / \mathrm{cm}^{3}$ ).

\section{ACKNOWLEDGEMENTS}

We would like to thank the management of the Paku Gajah Development Project, PT Pertamina EP for permission to use and publish the data. We would also like to thank the DRPM Universitas Indonesia for financial support of 2019 PITA's grant No. NKB-0640/UN2.R3.1/ HKP.05.00/2019 in publishing the result.

\section{REFERENCES}

Audley-Charles, M.G. 2004. Ocean trench blocked and obliterated by Banda forearc collision with Australian proximal continental slope. Tectonophysics 389(1-2): 65-79.

Bird, P.R. \& Cook, S.E. 1991. Permo-Triassic successions of the Kekneno area, West Timor: Implications for 
paleogeography and basin evolution. Journal of Southeast Asian Earth Sciences 6(3-4): 359-371.

Chamalaun, F.H. \& Grady, A.E. 1978. The tectonic development of Timor: A new model and its implications for petroleum geology. The APEA Journal 18(1): 102-108.

Charlton, T. 2002. The petroleum potential of West Timor. Twenty-Eighth Annual Convention and Exhibition Conference. doi. 10.29118/IPA.183.301.

Harris, R.A. 1991. Temporal distribution of strain in the active Banda orogen: A reconciliation of rival hypothesis. Journal of Southeast Asian Earth Sciences 6(3-4): 373-386.

Harsolumakso, A.H., Sapiie, B., Rudyawan, A., Tiranda, H., Reski, E. \& Fauziah, R. 2019. Understanding structural style of onshore Timor basin from detailed fieldwork. Modern Applied Science 13(4): 123-136.

Koesnama, K. \& Permana, A.K. 2015. Sistem minyak dan gas di cekungan Timor, Nusa Tenggara Timur. Jurnal Geologi dan Sumberdaya Mineral 16(1): 23-32.

Ricardo, N., Amijaya, H. \& Husein, S. 2017. Basin evolution palispatic model of Bonaparte basin, Australia Northwest Shelf. Journal of Applied Geology 2(2): 94-108.
Rosid, S. \& Setiawan, A.O. 2015. Basin identification at hydrocarbon prospect area, Banten using gravity data. In Proceedings of International Conference on Natural, Mathematical and Environmental Sciences (NAMES), Banjarmasin.

Sani, K., Jacobson, M.I. \& Sigit, R. 1995. The thin-skinned thrust structures of Timor. In Proceedings of the 24th Indonesian Petroleum Association. pp. 277-293.

Sawyer, R.K., Sani, K. \& Brown, S. 1993. The stratigraphy and sedimentology of West Timor, Indonesia. In Proceedings of the 22nd Indonesian Petroleum Association. 1: 533-574.

Physics Department

FMIPA Universitas Indonesia

Depok 16424

Indonesia

*Corresponding author; email: syamsu.rosid@ui.ac.id

Received: 15 January 2020

Accepted: 10 May 2020 